\title{
Exploring internal auditor independence motivators: Kenyan perspective
}

\author{
Charles Guandaru Kamau*, Samuel Kariuki Nduati, Agnes Ndinda Mutiso \\ Jomokenyatta University of Agriculture and Technology (JKUAT), Juja, Kenya \\ Email address: \\ guandaruman@yahoo.co.uk (C. G. Kamau), sankariuki@gmail.com (S. K. Nduati), mutisoagnes2@yahoo.com (A. N. Mutiso)
}

\section{To cite this article:}

Charles Guandaru Kamau, Samuel Kariuki Nduati, Agnes Ndinda Mutiso. Exploring Internal Auditor Independence Motivators: Kenyan Perspective. International Journal of Economics, Finance and Management Sciences. Vol. 2, No. 2, 2014, pp. 132-137.

doi: $10.11648 /$ j.ijefm.20140202.13

\begin{abstract}
The institute of internal auditors expressed the role of internal audit as that providing objective assurance and consulting services designed to add value and improve an organization's operations. In performing this role the internal auditors are required by the international standards to exercise professional independence and objectivity. Audit independence means freedom from conditions that threaten mental attitude which is unbiased. The literature suggests several factors which affect the audit independence in Kenya, which are explored in this study. The study collected its data using a self-made questionnaire which was distributed among auditors in Kenya so as to establish the status of internal auditor's independence in Kenya. The data collected was subjected to multiple regression analysis so as to test hypotheses and make conclusions on internal audit independence and its motivators in Kenya. The study established that that auditor's involvements in management and audit committee effectiveness, among other factors have significant influence on the internal auditor's independence in Kenya.
\end{abstract}

Keywords: Auditor Independence, Auditor Skills, Conflict of Interest, Kenya

\section{Introduction}

The IPPF standard number 1100 requires that an internal audit activity be independent and objective in performing its duties. The standard further clarifies that the chief audit executive should report to a level within the organization that allows the internal audit activity to fulfill its responsibilities. The internal audit activity should also be free from interference in determining the scope of internal auditing, performing work, and communicating results [1]. The standards also require the internal auditors to have an impartial, unbiased attitude and avoid conflicts of interest.

IIA [1] defines audit independence as "the freedom from conditions that threaten objectivity or the appearance of objectivity". Objectivity is defined as "an unbiased mental attitude that allows internal auditors to perform engagements in such a manner that they have an honest belief in their work product and that no significant quality compromises are made". Many countries examined have taken steps to enhance auditor independence by adhering to codes of ethics; promulgating professional auditing standards; and detailing situations that may constitute impairment of auditor independence [2].
Stewart and Nava [3] elucidates that the value and credibility of assurance services provided by auditors is derived from fundamental assumptions of independence of mind and independence in appearance. They further state that it is surprising that a large body of research has examined auditor independence and objectivity, but this has been predominantly in the context of external audit. This is one of the motivations for this particular study.

Internal auditing definition by IIA [1] clearly describes internal audit as an independent and objective assurance and consulting activity. This implies that it is mandatory for an internal audit function to operate independently for it to achieve its mandate effectively.

Several studies that have been carried out in Kenya indicate that internal audit departments' effectiveness ranges from in effective to averagely effective. These studies further highlights that auditor's independence is below average in most cases [4] [5] [6]. Internal audit effectiveness is strongly influenced by internal audit quality and management support [7]. Internal audit quality is enhanced by the department's independence and objectivity. The best support that management can offer internal audit department is by allowing it to operate with a reasonable degree of independence. This research will 
therefore explore internal audit independence motivators in a Kenya's perspective given that the studies that have so far been carried out have casted some doubts on the independence of internal audit departments.

The remainder of this paper is structured as follows. The first section provides a brief review of literature which includes the theories upon which this study is based. The second section briefly describes the methodology that was employed in this research. This section forms the basis for the formulation of the hypotheses that were tested. The third section provides an analysis of the motivators that impact upon the internal audit function's independence. The fourth section provides the results of the study and a critical analysis of the results relative to the theoretical position. The final section presents the conclusions and recommendations.

\section{Literature Review}

Several studies have been carried out on internal audit independence and objectivity. Review of literature identified some motivators of internal Audit independence which includes the following:

\subsection{Involvement by Internal Auditors in Management Activities}

Agency theory contends that internal auditing, in common with other intervention mechanisms like financial reporting and external audit, helps to maintain cost-efficient contracting between owners and managers [8].

In order to enhance the internal audit independence, auditors are not required to actively involve themselves in the day to day management of the organization. Their main concern should be risk management [1]. Drent [9] further added to the management influence theory, noting that executive and line management, by utilizing the internal audit function for various extended roles, do not always appreciate the need for independence. Drent [9] also argued that many executives and managers view internal auditors as their workers, and hence views internal auditors' reporting to the audit committee as merely a formality to satisfy corporate governance requirements. Since some managers believe that internal auditors are supposed to work for them, they induce the auditors to engage in management functions. It is in this area that the impairment of the internal audit function's independence poses a threat. Van Gansberghe [10] expressed the dilemma through an argument that the internal audit department is required to add value to management operations, while at the same time not become its servant, and dependably report on the status to the board or some other equivalent governing body.

The independence of the internal audit function is also affected negatively by the possibility for management to influence the budget of internal audit function. Further when senior management becomes too heavily involved in influencing the internal audit planning, this act poses a potential threat to the independence of the internal audit function [11]. Internal auditors who engage in management practices are more likely to have impaired audit independence.

\subsection{Audit Committee Effectiveness}

An audit committee is composed of a selected number of members of board of directors of a company. The responsibilities of the audit committee include helping auditors remain independent of management. The objectives of both internal auditing and the audit committee are complimentary and effective coordination produces symbiotic benefits for each and organization as a whole [12]. Firms whose audit committees have less financial expertise, less accounting financial expertise and non-accounting financial expertise are more likely to be faced with internal control weaknesses in their systems [13].

Goodwin and Yeo [14] established that the position of the internal audit function can be enhanced by an effective audit committee. Audit committee acts as an independent forum in which internal auditors may raise matters affecting management [15]. The audit committees in this instance then enhances to internal audit independence and objectivity by offering an alternative reporting channel. Goodwin [16] went a step further to point out that audit independence is enhanced if the members of the audit committee have the technical expertise to understand the work of the internal audit function in addition to being independent. This confirmed an earlier study by Raghunandan et al. [17] who established that those committees that are comprised exclusively of independent directors, and with at least one member having accounting or finance expertise, were more likely to have longer meetings with the CAE, to provide access to the CAE, and to review internal audit programs and results. Audit committees should play an oversight role on internal audit by assessing the independence and work performance of the internal audit function [18]. Audit committees therefore may form one of the critical ways of enhancing internal audit independence.

\subsection{Auditor Skills}

IIA Standard number 1210 requires internal auditors to possess the knowledge, skills, and other competencies needed to perform their individual responsibilities. The internal audit activity collectively is required possess or obtain the knowledge, skills, and other competencies needed to perform its responsibilities [1]. Auditors carry out their work by collecting audit evidence to support their conclusions. This act of evidence collection requires that the internal auditor be independent [19]. Collection of audit evidence is therefore a function of audit skills. Research has shown that most organizations prefer an in-house internal audit function, however one of the most important factors for those seeking to outsource is access to specialized skills [20]. This could mean that the auditors who are more skilled are likely to be more objective and independent while carrying out their work. Further studies have also hinted that the internal audit departments that have adopted IPPF and operates as per the requirements thereof usually maintains 
quality and hence are likely to be more independent [21]. According to Hass et' al [22], CBOK 2006 asserts that internal auditors need to possess increasing levels of critical thinking, analysis, decision making, and logic in order for them to handle the extended role of internal audit. This is an addition to the requirement of standard number 1210 . Internal auditors, who lack the necessary skills, may lack objectivity in their professional judgment hence negatively affecting the internal audit independence.

\subsection{Conflict of Interest}

Standard number 1120 requires that internal auditors must have an impartial, unbiased attitude and avoid any conflict of interest. The standard further explains conflict of interest as a situation in which an internal auditor, who is in a position of trust, has a competing professional or personal interest. Such competing interests can make it difficult to fulfill his or her duties impartially [1]. A number of employees use the internal audit function as a stepping stone to other higher positions [11]; this may pose a risk of conflict of interest and hence impair audit independence. According to Christopher and Leung [11] some of the threats to internal audit independence arising from conflict of interest includes, a situations where the chief executive officer (CEO) or chief finance officer (CFO) approve the internal audit's budget and even provide input for the internal audit plan; also where the management considers the internal auditor as a "partner"; and where CAEs do not report functionally to the audit committee.

\subsection{Research Gap}

Howard and Weiss [23] observed that internal auditor's lack of true independence from management is the main reason why the internal audit profession does not encourage management, and the board, to rely on internal audit's assessment of internal controls. Further Stewart and Subramaniam [3] concluded that it was clearly evident that internal audit independence and objectivity was a rich and fruitful area of investigation where researchers can make a valuable contribution to the on-going development of the profession.

Salehi and Azary [24] as were of the opinion that the provision of non-audit services among other issues caused the auditors not to produce a fair report. They therefore concluded that "auditor independence is a key element of the audit expectation gap" meaning that auditors who are independent helps in reducing the audit expectation gap. It is in line with this and the review of the literature that this study seeks to make a contribution on the status of internal audit independence in Kenya.

\section{Methodology}

The study collected its data using a self-made questionnaire which was distributed among auditors in Kenya so as to establish the status of internal auditor's independence in Kenya. The questionnaire was distributed through facebook groups such as accountants in Kenya and accountants on facebook. This questionnaire's reliability was tested using Cronbach's a coefficient and was determined to be 0.937 suggesting an excellent internal reliability of the questionnaire according to Kline [25]. This questionnaire was used to carry out a regression analysis on the motivators of internal audit independence in Kenya. The questionnaire was designed based on the Likert scale model with four choices; "strongly agree", "agree", "disagree", "strongly disagree" (5) represents strongly agree and (1) represents strongly disagree. A total of 21 questionnaires were fully filled and returned and hence they form the basis of results and discussions below.

\section{Results and Discussions}

A multiple regression analysis was carried out on the four independent variables (internal auditor's involvement in management, audit committees effectiveness, auditor skills and conflict of interest) against one dependent variable (auditor's independence) and the results were as shown in the table below:

Table 1. Multiple linear regression results table

\begin{tabular}{lllll}
\hline & Coefficients & $\begin{array}{l}\text { Standard } \\
\text { Error }\end{array}$ & t Stat & P-value \\
\hline Intercept & 3.048 & 0.780 & 3.906 & 0.001257 \\
X 1 & -1.121 & 0.188 & -5.932 & 0.0000211 \\
X 2 & 1.484 & 0.178 & 8.343 & 0.00000032 \\
X 3 & 0.609 & 0.185 & 3.299 & 0.004526 \\
X 4 & -0.183 & 0.148 & -1.24 & 0.230871 \\
\hline
\end{tabular}

Where:

$\mathrm{X}$ 1: internal auditor's involvement in management

$\mathrm{X}$ 2: audit committees effectiveness

$\mathrm{X}$ 3: auditor skills

$\mathrm{X}$ 4: conflict of interest

Table I above clearly shows that internal auditor's involvement in management, audit committees effectiveness and auditor skills significantly influence the internal auditor independence; while conflict of interest is not a significant motivator of auditor independence. When the table is reduced into a regression model, the following would be the form.

$$
\mathrm{Y}=3.048-1.121 \mathrm{X}_{1}+1.484 \mathrm{X}_{2}+0.609 \mathrm{X}_{3}
$$

Given that the values of $\mathrm{X} 1, \mathrm{X} 2$ and $\mathrm{X} 3$ were $2.43,2.71$ and 3.24 respectively, the level of auditor independence (Y) in Kenya is 6.32 which is an equivalent of a score of 3.16 . This indicates that a majority of the respondents beloved that internal auditors in Kenya were independent in their work. The reliability of the above model is supported by the following ANOVA table

Table 2. ANOVA results table

\begin{tabular}{llllll}
\hline ANOVA & $\boldsymbol{d} \boldsymbol{f}$ & $\boldsymbol{S S}$ & $\boldsymbol{M S}$ & $\boldsymbol{F}$ & Significance $\boldsymbol{F}$ \\
\hline Regression & 4 & 24.54415 & 6.136039 & 26.23949 & 0.0000007444 \\
Residual & 16 & 3.74156 & 0.233847 & & \\
Total & 20 & 28.28571 & & & \\
\hline
\end{tabular}

$\mathrm{H}_{0}$ : Relationship between $\mathrm{X}_{\mathrm{i}} \mathrm{s}$ and $\mathrm{Y}=0$, i.e. $\mathrm{X}_{\mathrm{i}} \mathrm{S}$ in the equation are not a good predictor of $\mathrm{Y}$ 
The critical $\mathrm{F}$ is estimated at 4.983 while the actual $\mathrm{F}$ is 26.239. This means that since the actual $F$ is more than the critical F statistic, null hypothesis is to be rejected. Therefore the Xis in the equation are good predictors of Y. Further, the significance level of the equation is almost zero hence the equation is a very strong representation of the actual status that internal auditor's involvement in management, audit committees effectiveness and auditor skills are major contributors of high auditor independence in Kenya.

The following table helps to explain the individual relationship between each of the independent variable and the dependent variable.

Table 3. Hypothesis Testing for Variables

\begin{tabular}{lllll}
\hline & t Stat & Critical t & P-value & Decision \\
\hline $\mathrm{X} 1$ & -5.932 & 2.086 & 0.0000211 & Reject $\mathrm{H}_{0}$ \\
$\mathrm{X} 2$ & 8.343 & 2.086 & 0.00000032 & Reject $\mathrm{H}_{0}$ \\
$\mathrm{X} 3$ & 3.299 & 2.086 & 0.004526 & Reject $\mathrm{H}_{0}$ \\
$\mathrm{X} 4$ & -1.24 & 2.086 & 0.230871 & Accept $\mathrm{H}_{0}$ \\
\hline
\end{tabular}

Where:

$\mathrm{X}$ 1: internal auditor's involvement in management

$\mathrm{X}$ 2: audit committees effectiveness

$\mathrm{X}$ 3: auditor skills

$\mathrm{X}$ 4: conflict of interest

Each of the variables is explained in the following subtopics

\subsection{Involvement by Internal Auditors in Management Activities}

Table 3 above clearly indicates that the null hypothesis in relation to internal auditor's involvement in management (X1) was rejected. The null hypothesis is stated here below.

$$
\mathrm{H}_{0}: \mathrm{X} 1=0 \text {, i.e. } \mathrm{X}_{1} \text { is not a good predictor of } \mathrm{Y}
$$

Rejecting null hypothesis implies that internal audit independence in Kenya is negatively affected by the internal auditor's involvement in the management. The more the internal auditors engage in management affairs, the less independent they become and vice versa. This finding agrees with the observation made by Christopher et' al [11]. Internal auditors should therefore refrain themselves from over engaging in management activities and restrict themselves to assurance and consultancy services that adds value to risk management and governance processes. This will greatly enhance their audit independence.

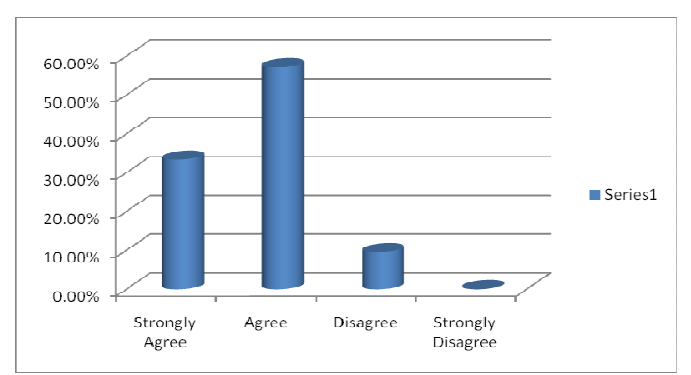

Figure 1. Bar graph on the internal auditor's involvement in management activities (Internal auditor's involvement in management affects their professional independence)
The results on Figure 1 above are based on a corroborative question as to whether internal auditor's involvement in management activities affects auditor's professional independence. Most of the respondents agreed with the position hence adding more weight to the regression and hypothesis testing results.

\subsection{Audit Committee Effectiveness}

Table 3 above clearly indicates that the null hypothesis in relation to audit committee's effectiveness (X2) was rejected. The null hypothesis is stated here below.

$$
\mathrm{H}_{0}: \mathrm{X} 2=0 \text {, i.e. } \mathrm{X}_{2} \text { is not a good predictor of } \mathrm{Y}
$$

Rejecting null hypothesis means that internal audit independence in Kenya is directly affected by the effectiveness of audit committees. The higher the degree of effectiveness of audit committees; the higher the auditor's independence level, and vice versa. This finding agrees with most of the studies that have been carried out [13] [14] [15]. It also emphasizes on the importance of audit committees in enhancing the internal auditor's independence. The internal auditors who report to audit committees functionally are likely to be independent a fact that most respondents agreed to as indicated in Fig. 2 below.

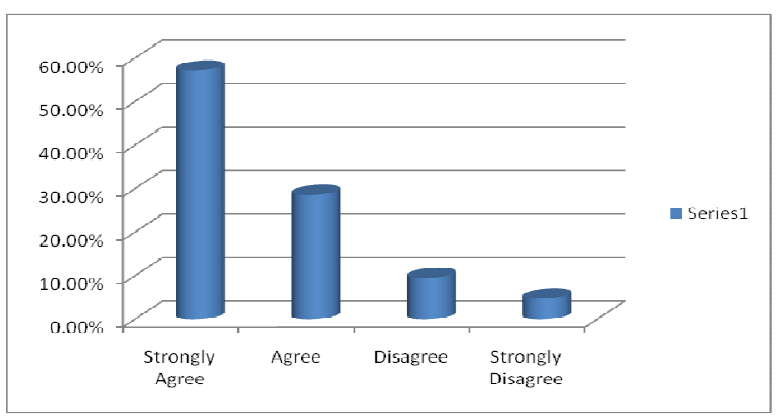

Figure 2. Bar graph on the audit committee's effectiveness (Effective audit committees enhances internal audit independence)

The results of fig 2 above are based on a corroborative question as to whether an effective audit committee enhances internal audit independence. Most of the respondents agreed with the position hence adding more weight to the regression and hypothesis testing results.

\subsection{Auditor Skills}

The results shown in Table 3 points out that the null hypothesis in relation to auditor skills (X3) was rejected. The null hypothesis is stated here below.

$$
\mathrm{H}_{0}: \mathrm{X} 3=0 \text {, i.e. } \mathrm{X}_{3} \text { is not a good predictor of } \mathrm{Y}
$$

Rejecting null hypothesis implies that auditor skills directly affect the internal auditor's independence. The higher the level of auditor skills; the higher the auditor's independence level, and vice versa. The internal auditors and internal audit departments should strive to acquire the 
skills highlighted by Hass et' al [22] and CBOK 2006 which includes critical thinking, analysis, decision making, and logic in order for them to handle the extended role of internal audit independently. The internal auditors who are well skilled are likely to be independent a fact that most respondents agreed to as indicated in Fig. 3 below.

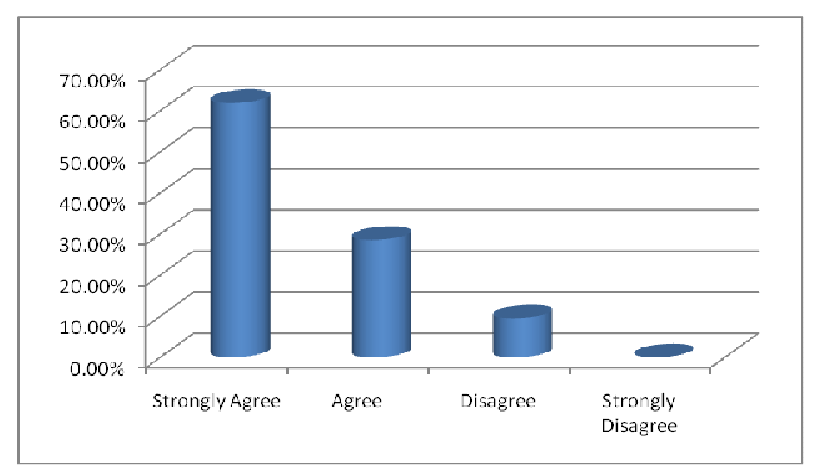

Figure 3. Bar graph on the internal auditor skills (Skilled internal auditors are likely to be more independent)

The results on Fig. 3 above are based on a corroborative question as to whether skilled internal auditors are likely to be more independent. Most of the respondents agreed with the position hence adding more weight to the regression and hypothesis testing results.

\subsection{Conflict of Interest}

The results shown in Table 3 points out that the null hypothesis in relation to conflict of interest by internal auditors (X4) was not rejected. The null hypothesis is stated here below.

\section{$\mathrm{H}_{0}: \mathrm{X} 4=0$, i.e. $\mathrm{X}_{3}$ is not a good predictor of $\mathrm{Y}$}

Failing to reject the null hypothesis means that conflict of interests by internal auditors does not have a significant affect the internal auditor's independence. The data analysis depicted an inverses relationship between conflict of interest and auditor independence. However the inverse relationship is not statistically significant. The hypothesis testing results conflicts with the corroborative question where most respondents agreed that conflict of interest affects auditor's independence to as indicated in Fig. 4 below.

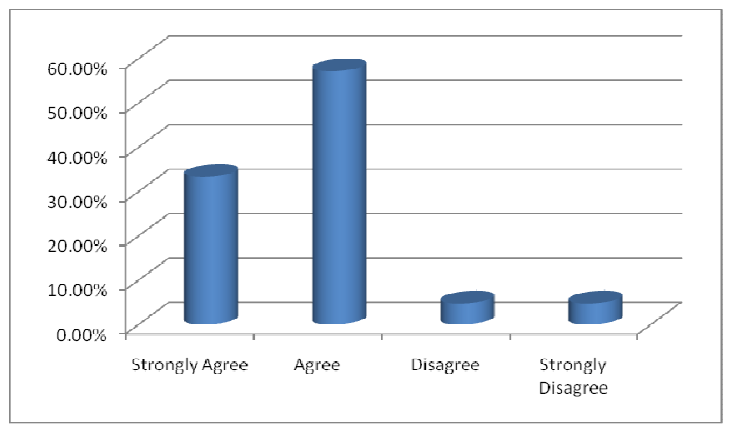

Figure 4. Bar graph on the conflict of interest (Conflict of interest by internal auditors affects their independence)
The results on Fig. 4 above are based on a corroborative question as to whether conflict of interest by internal auditors has an effect on their independence. Most of the respondents agreed with the position hence adding some weight to the regression and hypothesis testing results.

\section{Conclusion}

The institute of internal auditors through IPPF standard number 1100 requires that an internal audit activity be independent and objective in performing its duties. The internal audit activity should also be free from interference in determining the scope of internal auditing, performing work, and communicating results.

The researchers observed that the level of involvement by the internal auditors in the management activities significantly affects their professional independence. The study also observed that audit committees effectiveness also plays a significant role in enhancing audit independence. Organizations may therefore consider building capacity of the audit committees so as to improve internal audit independence. The study further found out that there is a statistically significant causal relationship between the level of internal auditor's skills and auditor independence in Kenya. However the study did not establish a significant effect of conflict of interest by internal auditors on the auditor independence despite a majority of the respondents affirming that indeed it actually have an effect. This study would therefore recommend further studies on the issue of conflict of interest by internal auditors especially in relation to its influence on internal audit independence.

\section{References}

[1] The Institute of Internal Auditors, The Professional Practices Framework. Florida, USA: Altamonte Springs, 2004.

[2] Vanasco, Rocco R., Clifford R. Skousen, and L. Roger Santagato. "Auditor independence: an international perspective." Managerial Auditing Journal 12.9 (1997): 498-505.

[3] Stewart, Jenny, and Nava Subramaniam. "Internal audit independence and objectivity: emerging research opportunities." Managerial auditing journal 25.4 (2010): 328-360.

[4] Ongeri, S. N., C. Okioga, and D. K. Okwena. "An Assessment of the Effectiveness of Internal Audit Systems in the Management of Decentralized Funds in Kenya: A Study of Local Authority Transfer Fund In Kisii Municipal Council." Scientific Conference Proceedings. 2013.

[5] Rono, E. (2006). Effectiveness of the internal control system in management of finances in public universities in Kenya. A masters project submitted to Egerton University.

[6] Oyugi, L. N. (2005). Fiscal Decentralization in Kenya: the case study of Local Authority Transfer Fund. A discussion paper downloaded from http://www.kenyagranery.or.ke/?p=/129 on 23/03/2010 
[7] Mihret, Dessalegn Getie, and Aderajew Wondim Yismaw. "Internal audit effectiveness: an Ethiopian public sector case study." Managerial Auditing Journal 22.5 (2007): 470-484.

[8] Adams, Michael B. "Agency theory and the internal audit." Managerial Auditing Journal 9.8 (1994): 8-12.

[9] Drent, D. (2002), "The duest for increased relevance: internal auditors who successfully communicate and balance their needs and those of their clients can increase their relevance to the organisation", Internal Auditor, Vol. 59 No. 1, pp. 49-54.

[10] Van Gansberghe, C.N. (2005), Internal Audit: Finding Its Place in Public Finance Management, The International Bank for Reconstruction and Development, The World Bank, Washington, DC

[11] Christopher, J., Sarens, G., \& Leung, P. (2009). A critical analysis of the independence of the internal audit function: evidence from Australia. Accounting, Auditing \& Accountability Journal, 22(2), 200-220.

[12] Verschoor, C. C. (2008). Audit committee essentials. Wiley. com.

[13] Zhang, Yan, Jian Zhou, and Nan Zhou. "Audit committee quality, auditor independence, and internal control weaknesses." Journal of accounting and public policy 26.3 (2007): 300-327.

[14] Goodwin, J. and Yeo, T.Y., "Two factors affecting internal audit independence and objectivity: evidence from Singapore", International Journal of Auditing, 5. 2 (2001): 107-25.

[15] Turley, S. and Zaman, M., "The corporate governance effects of audit committees", Journal of Management and Governance, 8.3 (2004): 305-32.

[16] Goodwin, J. (2003), "The relationship between the audit committee and the internal audit function - evidence from Australia and New Zealand", International Journal of
Auditing, Vol. 7 No. 3, pp. 263-78.

[17] Raghunandan, K.R., Read, W.J. and Rama, D.V. (2001), "Audit committee composition, gray directors, and interactions with internal auditing", Accounting Horizons, Vol. 15 No. 2, pp. 105-18.

[18] Schneider, A. (2010). ASSESSMENT OF INTERNAL AUDITING BY AUDIT COMMITTEES. Academy of Accounting \& Financial Studies Journal, 14(2).

[19] Kamau, C. G., \& Kariuki, S. N. (2012). Factors Influencing Sample Size for Internal Audit Evidence Collection in the Public Sector in Kenya. International Journal of Advances in Management and Economics, 1(2), 42-49.

[20] Selim, G. and Yiannakas, A. (2000), "Outsourcing the internal audit function: a survey of the UK public and private sectors", International Journal of Auditing, Vol. 4, pp. 213-226.

[21] Bichanga, W. O., \& Kamau, C. G. (2012). A study to explore internal auditors' compliance with Quality Assurance Standards: A case of state owned corporations in Kenya. International Journal of Research Studies in Management, $1(1)$.

[22] Hass, Susan, Mohammad J. Abdolmohammadi, and Priscilla Burnaby. "The Americas literature review on internal auditing." Managerial Auditing Journal 21.8 (2006): 835-844.

[23] Howard, John, and David D. Weiss. "True independence." Internal Auditor Oct. 2005: 13.

[24] Salehi, M., Mansouri, A., and Azary, Z. (2009) "Independence and Audit Expectation Gap: Empirical Evidence from Iran", International Journal of Economic and Finance. 1, 165-174.

[25] Kline, P. (2000). The handbook of psychological testing (2nd ed.). London: Routledge 